\author{
Jurnal E-KOMTEK (Elektro-Komputer-Teknik) \\ Vol. 4, No. 2 (2020) pp. 191-199 \\ https://jurnal.politeknik-kebumen.ac.id/index.php/E-KOMTEK \\ p-ISSN : 2580-3719 \\ e-ISSN : 2622-3066
}

\title{
Perancangan Sistem Informasi Alumni Berbasis Website dengan Menggunakan PHP MYSQL di Politeknik Dharma Patria Kebumen
}

\author{
Danny Saputra ${ }^{1^{*}}$, Ari Waluyo ${ }^{2}$ \\ ${ }^{1}$ Sistem Informasi, Politeknik Piksi Ganesha, Bandung, Indonesia, 40274 \\ ${ }^{2}$ Teknik Elektronika, Politeknik Dharma Patria, Kebumen, Indonesia, 54316 \\ *E-mail : dannysaputra26.ds@gmail.com \\ Doi $\quad$ : https://doi.org/10.37339/e-komtek.v4i2.406
}

\section{Diterbitkan oleh Politeknik Dharma Patria Kebumen}

\section{Info Artikel \\ Diterima : \\ 09-12-2020 \\ Diperbaiki : \\ 17-12-2020 \\ Disetujui : \\ $17-12-2020$}

\begin{abstract}
ABSTRAK
Penelitian ini bertujuan untuk mengetahui sistem website alumni dengan menggunakan PHP MySQL yang sedang berjalan di Politeknik Dharma Patria Kebumen. Metode penelitian yang digunakan adalah dengan observasi di tempat penelitian, wawancara dan kajian pustaka. Oleh karena itu, diperlukan sebuah perancangan sistem website alumni dengan menggunakan $P H P M y S Q L$ dengan basis data yang lebih terintegrasi agar website alumni dapat diakses secara global lebih efektif dan efisien. Konsep dari perancangan sistem informasi ini menggunakan pendekatan berorientasi objek dengan pemodelan UML (Unified Modelling Language). Sedangkan metode pengembangan perangkat lunak waterfall yang digunakan dan menggunakan basis data MySQL. Hasil pengujian pada sistem website alumni di Politeknik Dharma Patria Kebumen dapat digunakan dengan baik dan efektif sebagai database alumni yang lengkap.

Kata kunci: Perancangan; PHP MYSQL; Website.
\end{abstract}

\section{ABSTRACT}

This study aims to determine the alumni website system using PHP MySQL which is currently running at the Dharma Patria Polytechnic, Kebumen. The research method used is observation at the research site, interviews and literature review. Therefore, it is necessary to design an alumni website system using PHP MySQL with a more integrated database so that the alumni website can be accessed globally more effectively and efficiently. The concept of designing this information system uses an object-oriented approach with UML (Unified Modeling Language) modeling. While the waterfall software development method used and uses the MySQL database. The test results on the alumni website system at the Dharma Patria Polytechnic Kebumen can be used properly and effectively as a complete alumni database.

Keywords: Design; PHP MYSQL; Website.
Alamat Korespondensi $\quad$ : Jl. Letnan Jenderal Suprapto No.73 Kebumen, Jawa Tengah, Indonesia 55431 This work is licensed under a Creative Commons Attribution-NonCommercial 4.0 International License. 


\section{PENDAHULUAN}

Dalam era teknologi globalisasi dewasa ini, komputer adalah sebagai salah satu teknologi informasi yang sangat dibutuhkan keberadaannya hampir di setiap kalangan aspek kehidupan. Perangkat komputer di gunakan sebagai perangkat pendukung dalam pengelolaan manajemen data yang sangat tepat dengan mempertimbangkan kuantitas dan kualitas data, dengan penggunaan perangkat komputer dalam setiap informasi sangat signifikan dalam mendukung sistem pengambilan keputusan.

Data alumni ini merupakan salah satu contoh dalam suatu sistem informasi yang di rancang untuk dapat membantu pekerjaan dalam suatu instansi pendidikan khususnya diperguruan tinggi dalam mengolah data sampai memberikan data secara lengkap dan tersedianya layanan informasi berbasis web ini. Data-data tersebut meliputi nama, angkatan, tempat tinggal, pekerjaan, kesan pesan dan beberapa tambahan data lainnya. Alumni juga berperanan penting untuk pengembangan institusi pendidikan dan sebagai cermin kualitas dalam sebuah institusi pendidikan diranah publik.

Dengan adanya sistem informasi tentang alumni di Politeknik Dharma Patria Kebumen, baik secara tidak langsung dapat meningkatkan citra baik perguruan tinggi terhadap masyarakat luas. Sampai saat ini masih banyak Perguruan Tinggi yang belum memanfaatkan suatu sistem informasi dalam pendataan dan penelusuran alumni untuk mempermudah dalam hal pengolahan dan pengelolaan data alumni tersebut, selain itu dengan sistem informasi alumni ini dapat memfasilitasi berbagai keperluan tambahan seperti berita, penelusuran alumni, dan informasi kegiatan lowongan pekerjaan.

\section{MATERIAL DAN METODE}

\subsection{Material}

a. Functional Design (Rancangan Fungsional)

Rancangan fungsional adalah penjelasan tentang fungsi-fungsi apa saja yang dapat dilakukan oleh suatu sistem. Perancangan sistem informasi tahap lanjutan merupakan analisa suatu sistem dimana pada perancangan sistem digambarkan sistem yang akan dibangun sebelum dirancang pengkodean dalam suatu bahasa pemrograman.

Dari analisa sistem baru dapat dibuat suatu hasil rancangan sistem, maka diusulkan perancangan sistem sebagai berikut : 


\section{b. Use Case Diagram}

Diagram di bawah ini memperlihatkan kegiatan yang dilakukan oleh aktor yang mencakup seluruh aktifitas pengelolaan website alumni di Politknik Dharma Patria Kebumen [1]. Use case Diagram website alumni di sajikan pada Gambar 1.

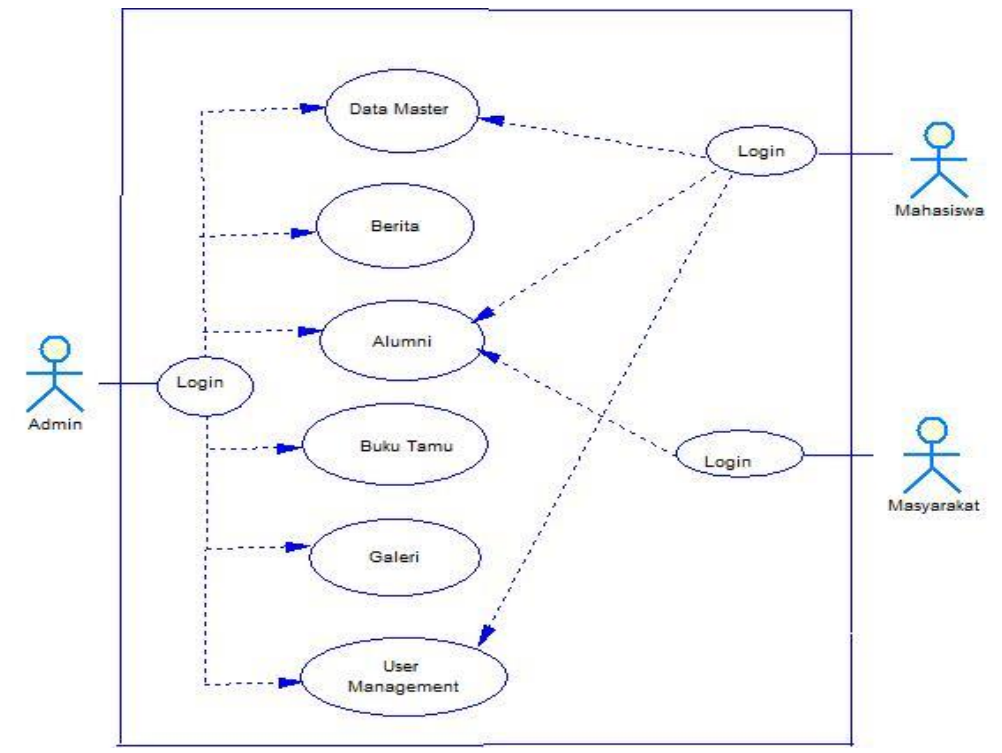

Gambar 1. Use Case Diagram Website Alumni

\section{c. Class Diagram}

Diagram di bawah ini memperlihatkan himpunan kelas-kelas dan kolaborasi-kolaborasi serta relasi-relasi [2]. Class Diagram website alumni di sajikan pada Gambar 2.

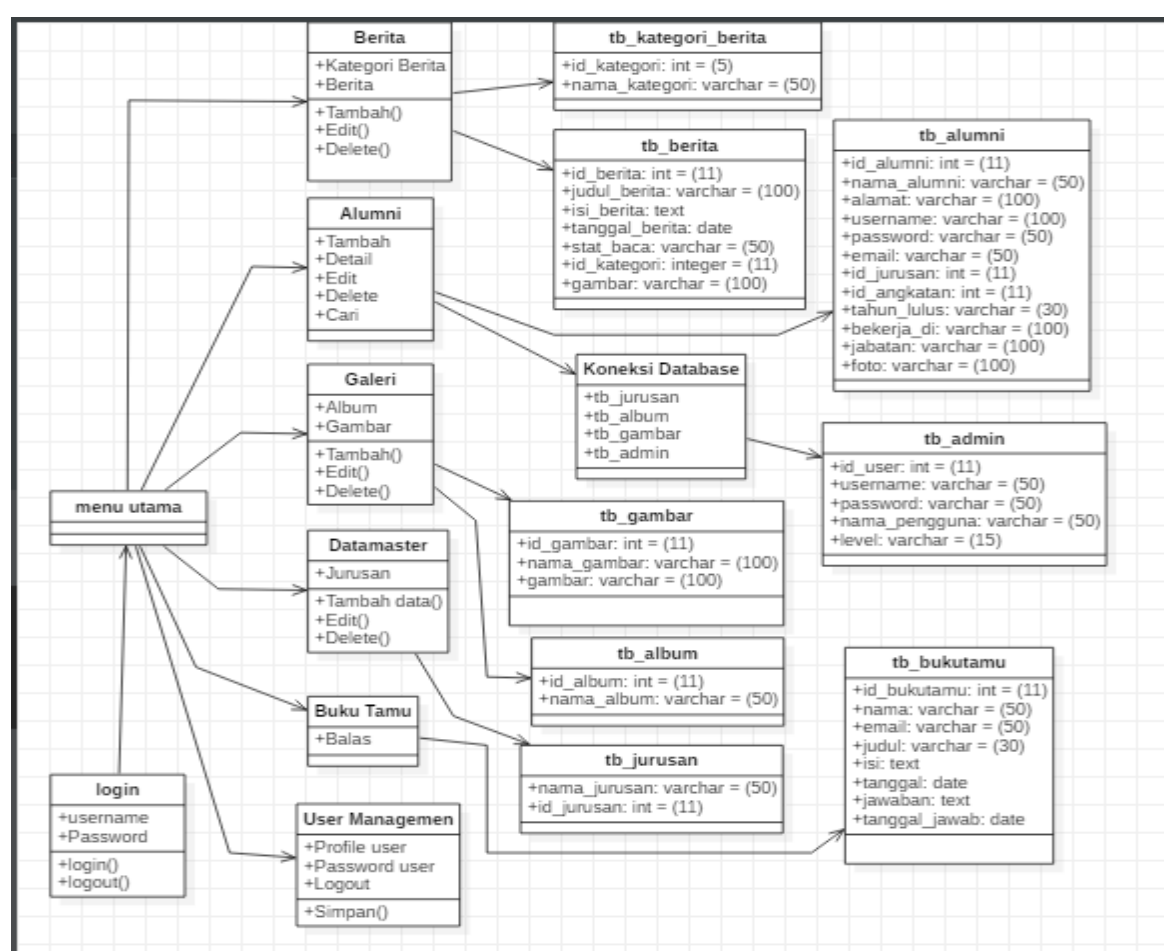

Gambar 2. Class Diagram Website Alumni 


\section{d. Alumni}

Alumni seseorang yang bisa dikatakan alumni yang telah menempuh suatu pendidikan dan lulus dari sebuah sekolah, perguruan tinggi, ataupun Universitas bahkan bisa diartikan dalam arti lain mantan anggota, karyawan, konstributor atau tahanan [3].

\section{e. Database (Basis Data)}

Basis Data merupakan suatu kumpulan data yang disimpan secara bersama-sama pada suatu media dan saling terhubung, yang diorganisasikan berdasarkan sebuah skema maupun struktur tertentu dan dilengkapi software - software untuk melakukan manipulasi data untuk kegunaan tertenetu.

\section{f. $\quad$ UML (Unified Modeling Language)}

UML (Unified Modeling Language) merupakan tujuan umum, perkembangan, bahasa pemodelan dalam bidang rekayasa perangkat lunak, dimaksudkan untuk menyediakan untuk memvisualisasikan desain sistem dengan cara standar [4].

\section{g. Blackbox Testing}

Pengujian dilakukan hanya mengamati hasil yang di eksekusi melalui data uji dan memeriksa fungsional dari perangkat lunak [5]. Jadi dianalogikan seperti kita melihat suatu kotak hitam, kit hanya bisa melihat penampilan luarnya saja, tanpa tau ada apa dibalik bungkus hitam nya. Sama seperti pada pengujian black box, mengevaluasi dari tampilan luarnya (interface nya), hanya mengetahui input dan output dan fungsionalitasnya tanpa mengetahui apa sesungguhnya yang terjadi dalam proses detilnya .

\section{h. $\quad$ Page Hyopertext Preprocessor (PHP)}

PHP (Page Hyopertext Preprocessor) adalah bahasa server-side -scripting menyatu dengan HTML untuk membuat halaman web yang dinamis [6]. Karena PHP merupakan suatu serverside-scripting maka sintaks dan perintah-perintah PHP akan diesksekusi diserver kemudian hasilnya akan dikirimkan ke browser dengan format HTML. Dengan demikian kode program yang ditulis dalam suatu PHP tidak akan terlihat oleh user sehingga keamanan halaman web lebih dapat terjamin. PHP dirancang untuk membuat halaman web yang dinamis, halaman web yang dapat membentuk suatu tampilan - tampilan berdasarkan permintaan terupdate, seperti menampilkan isi basis data di halaman web. 


\section{i. Website}

Website adalah suatu halaman web yang saling terhubung dan file-filenya saling terkait [3]. Web ini terdiri dari page atau halaman, dan kumpulan halaman yang dinamakan homepage. Homepage berada pada posisi teratas, dengan halaman-halaman yang terkait berada di bawahnya. Biasanya setiap halaman di bawah homepage disebut child page dan berisi hyperlink ke halaman lain dalam suatu web.

j. Domain

Domain adalah sebuah nama yang unik yang ditujukan untuk mengidentifikasi nama nama sebuah server komputer seperti email server atau web server pada jaringan komputer maupun internet [7]. Domain juga berfungsi untuk sarana dan mempermudah user (pengguna) internet saat mengakses dalam sebuah server, dan dapat juga dipakai sebagai pengingat nama server yang akan dikunjungi tanpa harus melewati sejumlah deretan angka yang cukup rumit yang disebut dengan alamat IP. Nama domain sering juga dikenal sebagai kesatuan dari sebuah situs contohnya politeknik-kebumen.ac.id. Nama domain juga sering orang menyebutnya dengan istilah link, alamat website atau URL [8].

\subsection{Metode}

Proses dalam pengembangan sistem registrasi pelayanan ini yang digunakan dalam penelitian ini terdiri dari berbagai langkah-langkah [9] menggunakan Prototipe Alat yang di gunakan untuk membantu pemodelan sistem adalah Unified Modelling Language (UML) [10] :

\section{a. Observasi}

Observasi lapangan yang secara langsung melakukan pengamatan terhadap sistem yang sedang berjalan yang sesuai alur data dan prosedur di Politeknik Dharma Patria Kebumen. b. Wawancara

Wawancara yaitu pencarian data melalui proses tanya jawab langsung dengan orangorang yang terlibat langsung maupun dengan pihak terkait secara langsung maupun tidak.

\section{c. Studi Pustaka}

Melakukan Studi pustakaan dengan mengumpulkan data - data dan informasi mengenai prosedur sistem yang ada, analisa percangan sistem berorientasi objek dan Bahasa pemrograman yang dapat dijadikan acuan pembahasan dalam masalah - masalah yang ada. 


\section{HASIL DAN PEMBAHASAN}

\subsection{Hasil}

Berdasarkan hasil yang di analisis oleh penulis di lakukan selama observasi di Politeknik Dharma Patria Kebumen, dan mengamati langsung kegiatan yang berhubungan dengan prosedur serta proses sistem - sistem yang berjalan pada saat ini.

Kelemahan-kelemahan dari proses publikasi alumni yang sedang berjalan adalah:

a. Tidak adanya halaman khusus yang dapat diakses oleh alumni maupun masyarakat luas untuk mengetahui alumni yang ada di Politeknik Dharma Patria.

b. Masyarakat luas belum dapat mengakses secara luas tentang data alumni dan biodata biodata para alumni.

\subsection{Pembahasan}

a. Tampilan Login

Dibawah merupakan tampilan Halaman login website dengan memasukkan username dan password pengguna atau operator maka akan dapat mengakses Sistem Alumni. Tampilan login disajikan pada Gambar 3.

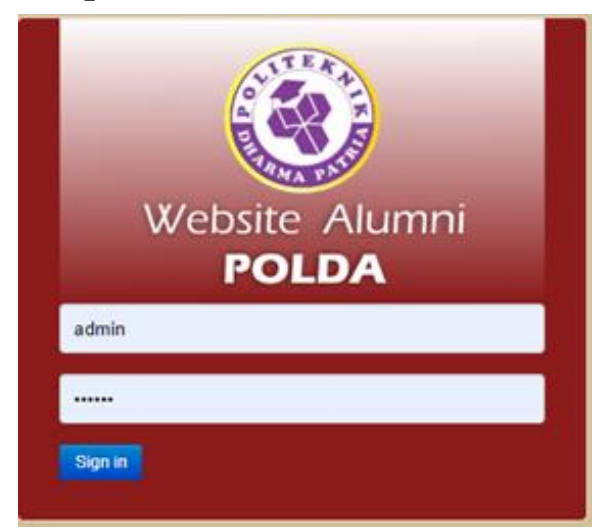

Gambar 3. Tampilan login

\section{b. Tampilan Home}

Dibawah merupakan tampilan awal ketika login berhasil, dan terdapat beberapa menu lainnya yang bisa di akses oleh si pengguna atau User. Tampilan home disajikan pada Gambar 4. 


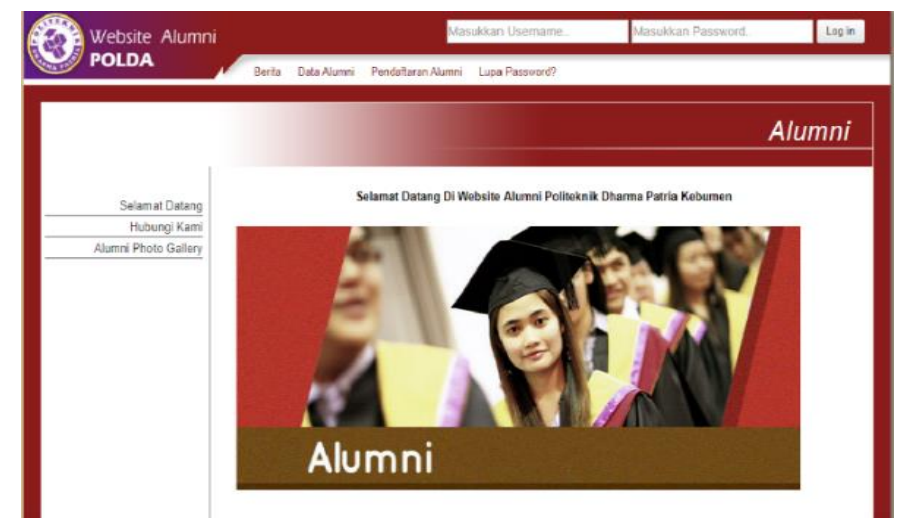

Gambar 4. Tampilan Home

c. Tampilan Data Alumni Sesuai Tahun Kelulusan

Dibawah ini merupakan hasil tampilan dari data-data alumni mahasiswa dari tahun ke tahun. Data alumni sesuai tahun kelulusan disajikan pada Gambar 5.

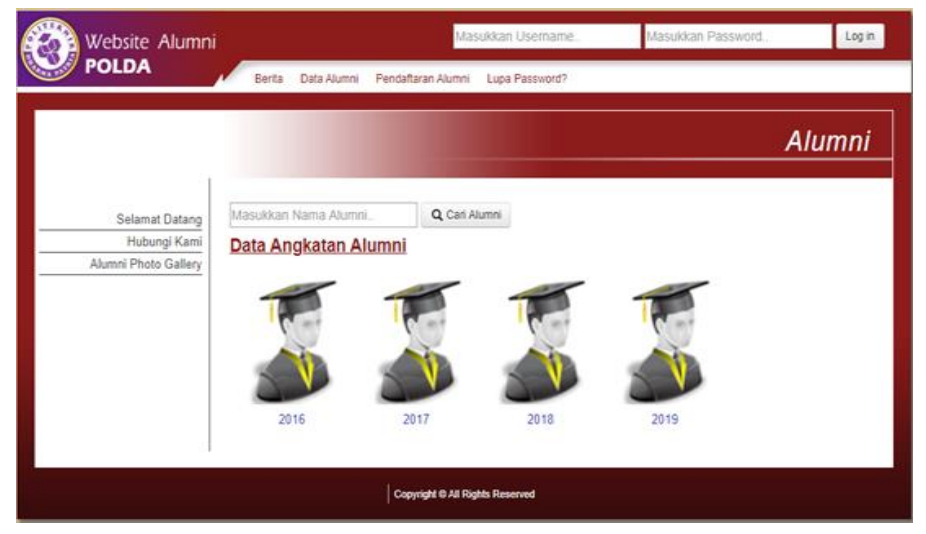

Gambar 5. Data Alumni Sesuai Tahun Kelulusan

d. Tampilan Form Input Data Alumni

Dibawah ini adalah tampilan untuk menginputkan data-data bagi para alumni yang akan di masukan ke dalam system. Form Input Data Alumni disajikan pada

\section{Gambar 6.}

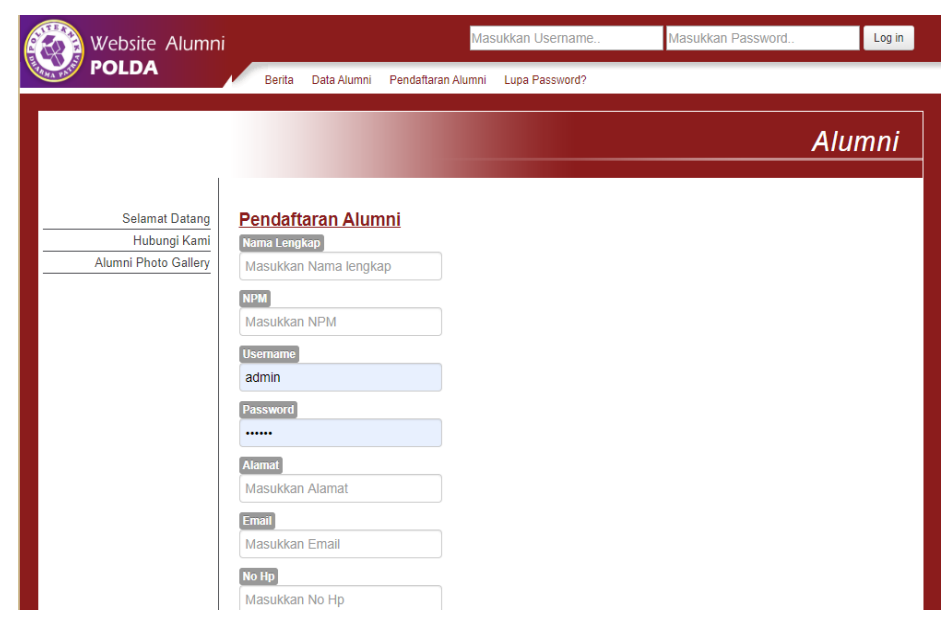

Gambar 6. Form Input Data Alumni 
e. Tampilan Hasil inputan Data Alumni

Hasil dari data yang telah di inputkan sesuai dengan form data para alumni yang telah terdaftar disajikan pada Gambar 7.

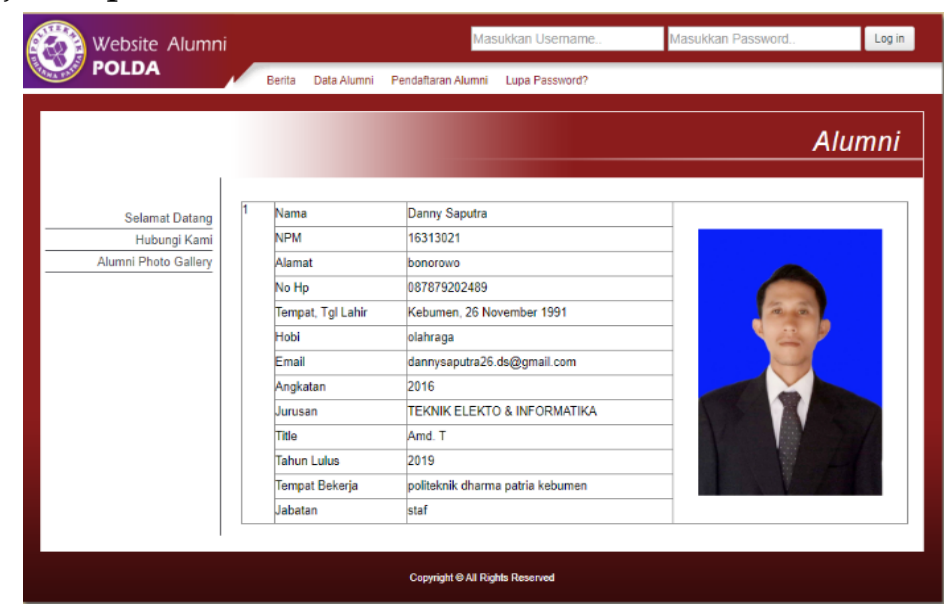

Gambar 7. Hasil inputan Data Alumni

Dari hasil perancangan sistem informasi website alumni ini dapat berfungsi dengan baik dan efektif dan dapat di aplikasikan sebagai wadah dan sarana informasi bagi para alumni Politeknik Dharma Patria berbagai angkatan dari tahun ke tahun, untuk mengetahui data dan informasi bagi para alumni.

\section{KESIMPULAN}

Perancangan Sistem Informasi website alumni dengan menggunakan PHP MySQL di Politeknik Dharma Patria Kebumen merupakan suatu pengembangan dari sistem yang sudah ada. Dari berbagai permasalahan-permasalahan yang muncul diharapkan dapat segera ditangani dengan adanya sistem yang baru ini, adapaun kesimpulan-kesimpulan yang dapat diambil antara lainnya :

a. Sistem informasi website alumni memerlukan data Alumni-Alumni Politeknik Dharma Patria.

b. Sistem informasi website alumni dapat digunakan oleh Alumni, dan masyarakat luas untuk mendapatkan informasi terkait lulusan dan infomasi para Alumni dari tahun ke tahun.

c. Sistem informasi website alumni yang dirancang ini dapat mempermudah untuk mengakomodir dan memberikan sumbangsih informasi yang falid yang dibandingkan dengan sistem yang sedang berjalan saat ini yaitu tingkat keamanan dalam penyimpanan data-data alumni. 


\section{REFERENSI}

[1] E. Y. P. Rimporok Erwin Billy, "Sistem Informasi Alumni Fakultas Ilmu Komputer Universitas Klabat," Konf. Nas. Sist. Inform. 2015, pp. 9-10, 2015.

[2] A. Nuari, "Sistem Informasi Tracer Study Berbasis Web," pp. 1-7.

[3] I. hajar Muhamad agus darsoni, "Seminar Nasional Industri dan Teknologi (SNIT), Politeknik Negeri Bengkalis," Perbandingan Pengguna. Bahan Bakar Prem. dan Gas Terhadap Daya dan Konsumsi Bahan Bakar Pada Genset Daito 1500 Watt, pp. 270-276, 2016.

[4] S. Japit, "Perancangan Sistem Informasi Alumni pada SMK Swasta Parulian 3 Medan," J. Ilm. Core It, no. $x, 2017$.

[5] C. K. Sastradipraja, G. Darmawan, and J. Hadi, "Perancangan Arsitektur Sistem Informasi Absensi dan Penggajian Menggunakan Framework Zachman," J. E-Komtek, vol. 4, no. 1, pp. 1-15, 2020, doi: 10.37339/e-komtek.v4i1.139.

[6] Y. A. Binarso, E. A. Sarwoko, and N. bahtiar Ba, "Pembangunan Sistem Informasi Alumni Berbasis Web Pada Program Studi Teknik Informatika Universitas Diponegoro," J. Informatics Technol., vol. 1, no. 1, pp. 72-84, 2012, [Online]. Available: https://ejournal3.undip.ac.id/index.php/joint/article/view/434.

[7] H. Herrmann and H. Bucksch, Eds., "domain BT - Dictionary Geotechnical Engineering/Wörterbuch GeoTechnik: English-German/Englisch-Deutsch," Berlin, Heidelberg: Springer Berlin Heidelberg, 2014, p. 400.

[8] J. M. Morel, B. Teissier, and P. K. Maini, "Lecture notes in mathematics," Lect. Notes Math., vol. 2084, 2013.

[9] N. W. Fais Irfandi Ari, "Perancangan Sistem Pendukung Keputusan Pemilihan Pegawai Teladan Menggunakan Metode Saw (Simple Additive Weighting) Berbasis Web Di Dinas Penanaman Modal Dan Pelayanan Terpadu Satu Pintu Kabupaten Kebumen," J. E-Komtek, vol. 3, no. Vol 3 No 2 (2019), pp. 71-86, 2019, [Online]. Available: https://jurnal.politeknikkebumen.ac.id/index.php/E-KOMTEK/article/view/132.

[10] H. T. SIHOTANG, "Sistem Informasi Pengagendaan Surat Berbasis Web Pada Pengadilan Tinggi Medan,” vol. 3, no. 1, pp. 6-9, 2019, doi: 10.31227/osf.io/bhj5q. 